\title{
KONSEP PENDIDIKAN KELUARGA MENURUT HASAN LANGGULUNG DAN RELEVANSINYA DENGAN PENGEMBANGAN KESEHATAN MENTAL KELUARGA
}

\author{
Ahmad Muda Harahap \\ UIN Imam Bonjol Padang \\ Email: ahmadmuda_harahap18@yahoo.com
}

\begin{abstract}
This article aims to describe and analyze the concept of family education according to Hasan Langgulung and its relevance to the development of family mental health. This study uses a character research method using descriptive qualitative approach. Hasan Lagulung' concept is as data in this research. The results of the study shows that the six aspects of family education namely physical education and health, intellectual education, emotional education, religious education social education aspects can develop children's potential on cognitive, affective, psychomotor, and spiritual. It is concluded that the development of this potential impacts on family mental health. It implies that if the first aspect does not work well, it impacts on other aspects.
\end{abstract}

Key Words: Family education, health, mentally.

\section{PENDAHULUAN}

Pendidikan keluarga merupakan pendidikan yang berlangsung dalam keluarga yang dilaksanakan oleh orang tua sebagai tugas dan tanggungjawabnya untuk mendidik anak-anaknya (Djamarah, 2014: 2). Pendidikan keluarga memberikan pengetahuan dan keterampilan dasar, agama, kepercayaan, nilai moral, norma sosial, dan pandangan hidup yang diperlukan anak untuk dapat hidup dalam keluarga dan di masyarakat.

Keluarga merupakan lingkungan pendidikan pertama dan utama bagi anak. Keluarga disebut sebagai lingkungan pendidik pertama karena keluarga merupakan tempat pertama dalam interaksi pendidikan anak. Sebelum anak memasuki usia sekolah, lingkungan sosial pertama baginya adalah keluarga. Keluarga seharusnya mampu menjadi ruang pertama bagi berlangsungnya edukasi dari orang tua kepada anaknya. Orang tua menjadi sentral dalam memberikan pengasuhan, perhatian dan pengalaman. Dalam sebuah hadist Rasulullah saw. bersabda:

$$
\begin{array}{r}
\text { كل مولود يولد على الفطرة فأ بو اه يهودانه أو ينصر انه } \\
\text { يمجسانه (رواه البخارى) }
\end{array}
$$

Artinya: Setiap anak dilahirkan dalam keadaan fitrah, maka kedua ayah dan ibunyalah yang menjadikannya Yahudi, Nasrani atau Majusi. (HR. Bukhari).

Hadist ini berimplikasi pada tanggung jawab orang tua terhadap anaknya. Orang tua sebagai orang yang terdekat mempunyai tanggung jawab yang sangat besar terhadap keberhasillan anak dalam menyelesaikan tugas perkembangannya. Orang tua diharapkan 
dapat memberikan arah, memantau, mengawasi, dan membimbing anak mereka. Dalam Alquran tersirat tanggung jawab orang tua dalam mendidik anaknya, Allah SWT berfirman dalam Alquran sebagai berikut:

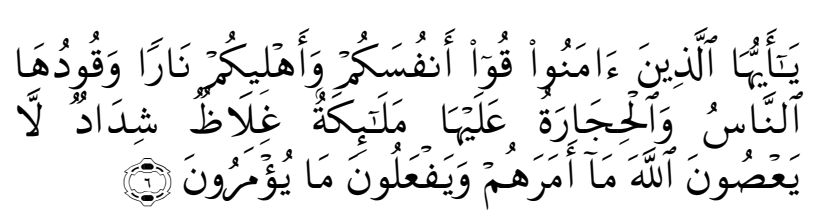

Artinya: Hai orang-orang yang beriman, peliharalah dirimu dan keluargamu dari api neraka yang bahan bakarnya adalah manusia dan batu; penjaganya malaikat-malaikat yang kasar, keras, dan tidak mendurhakai Allah terhadap apa yang diperintahkan-Nya kepada mereka dan selalu mengerjakan apa yang diperintahkan (QS. At-Tahrim: 6).

Ayat ini mengambarkan tangung jawab orang tua dalam bentuk penjagaan hak dasar anak dalam pemeliharaan dan pengembangan potensi akal dan kepribadiannya. Kewajiban orang tua pada pendidikan anak, tidak akan selesai dengan menyekolahkannya. Ketika anak memasuki bangku sekolah, orang tua perlu berkomunikasi dengan sekolah untuk meninjau dan membantu proses perkembangan anak, sehingga terjadi keseragaman pemberian pendidikan antara rumah dan sekolah. Orang tua tidak bisa lepas dari tanggung jawabnya, karena pola pendidikan keluarga berbeda dengan pendidikan formal maupun nonformal. Pendidikan keluarga lebih mengedepankan aspek kasih sayang, sehingga anak merasa lebih nyaman (Musmalim, 2011: 17).

Menurut Zakiah Daradjat keluarga adalah lembaga pendidikan yang pertama dan utama. Maksud pendidikan pertama adalah sebelum anak-anak mendapat pendidikan dari lembaga pendidikan (sekolah) mereka telah memperoleh pendidikan dari keluarga. Sehingga perlu diketahui bahwa keluarga merupakan lingkungan pendidikan pertama yang bertanggungjawab penuh atas pembentukan moral dan penanaman nilai terhadap anak. Sedangkan maksud pendidikan utama adalah keluarga yang paling tepat untuk menanamkan nilai yang baik kepada anak (Daradjat, 1996: 38).

Selain Zakiah Daradjat, Hasan Langgulung juga merupakan tokoh pendidikan Islam yang memberikan perhatian terhadap pendidikan keluarga. Paling tidak dari aktivitas dan keterlibatan Hasan Langgulung dalam organisasi pendidikan dan pengajaran diberbagai Negara Asia, Eropa dan Amerika menunjukkan bahwa ia berhasil mengembangkan bidang keahliannya, sekaligus menjadi bukti pengakuan masyarakat atas ketokohannya. Hasan Langgulung juga memiliki karya-karya yang umumnya menjadi salah satu rujukan utama bagi penulis dan peneliti pendidikan Islam. Hal ini menunjukkan bahwa Hasan Langgulung adalah tokoh yang memiliki pengaruh yang cukup kuat, khususnya dikalangan masyarakat pendidikan Islam.

Sementara itu, Karwadi menjelaskan bahwa Hasan Langgulung merupakan pemikir pendidikan Islam yang memberikan perhatian besar kepada proses pendidikan yang terstruktur dan sistematis. Pendidikan harus direncanakan dan dijalankan secara tersturuktur dengan tujuan tertentu sesuai 
dengan tahap umur dan tingkat pendidikan. Dengan cara ini dimungkinkan tidak terjadi pengulangan tujuan yang ingin dicapai dan materi yang disampaikan (Karwadi, 2009: 146). Lebih lanjut Karwadi menjelaskan bahwa Hasan Langgulung memandang pendidikan harus mempunyai daya guna secara langsung yang bersifat paraktis. Ini penting untuk meminimalisir pendidikan yang cenderung bersifat normatif dan melangit.

Sebagai seorang tokoh pemikir pendidikan Islam, Hasan Langgulung sangat intens dan memberikan perhatian besar terhadap dunia pendidikan, terutama pendidikan keluarga. Pemikiran Hasan Langgulung tentang pendidikan keluarga dalam Islam menjadi tema yang mendasar dalam merespon berbagai persoalan masyarakat dan pendidikan. Karena Hasan Langgulung melihat peran dan fungsi keluarga dari dua sisi, yakni masyarakat dan individu, sehingga keluarga dari sudut pandangnya adalah institusi pendidikan yang sangat penting. Menurutnya, berbagai penyimpangan peserta didik menjadi salah satu parameter tingkat keberhasilan dan kegagalan orang tua dalam mendidik anaknya di lingkungan pendidikan keluarga (Langgulung, 2004: 346).

Hasan Langgulung juga menyatakan pentingnya keluarga dalam proses pendidikan bukan hanya bagi individu, namun bagi masyarakat luas, sehinggga masyarakat menganggap bahwa keluarga merupakan institusi sosial terpenting dan unit sosial yang utama. Melalui individu-individu dipersiapkan, kemudian nilai-nilai kebudayaan, kebiasaan dan tradisi dipelihara kelanjutannya, dan melaluinya juga kebudayaan dipindahkan dari generasi ke generasi berikutnya. Dari segi lain jika susunan dan struktur keluarga itu sehat, maka struktur masyarakat pun akan sehat, sedangkan jika keluarga itu sakit maka masyarakat pun akan sakit, selanjutnya kehidupan masyarakatnya akan runtuh disebabkan runtuhnya sendisendi kehidupan yang terpenting (Langgulung, 2004: 346).

Di sisi lain, pemikiran Hasan Langgulung tentang pendidikan keluarga Islam juga mengemban tugas yang sangat penting, yakni bagaiman membina kesehatan mental para anggota keluarga agar dapat berperan aktif dan survive di era globalisasi. Kehidupan modern saat ini telah tampil dalam dua wajah yang saling bertentangan. Di satu sisi, era globalisasi ini telah berhasil mewujudkan kemajuan yang sangat pesat, khususnya dalam bidang ilmu pengetahuan dan teknologi. Namun di sisi lain, ia telah menyeret manusia pada kesengsaraan mental yang menyebabkan manusia sakit secara mental. Oleh sebab itu, pembinaan kesehatan mental dalam keluarga sangat penting dan menjadi sutau keniscayaan.

Kesehatan mental merupakan salah satu bagian dari psikologi, yang berkaitan dengan kesejahteraan dan kebahagiaan manusia, yang mencakup semua bidang hubungan manusia, baik hubungan dengan dirinya sendiri, hubungan dengan orang lain, maupun hubungannya dengan lingkungan serta hubungannya dengan Tuhan (Jaya, 1995: 15). Dalam dunia pendidikan Islam yang diharapkan adalah kesehatan mental yang positif agar generasi muda dapat berkembang maju, berkarakter, dan berahklak mulia. Dengan kata lain pelaksanaan pendidikan keluarga yang bertujuan untuk membina 
karakter anak, hendaknya berimplikasi pada kesehatan mental anak.

Menurut Hasan Langgulung, dalam konteks pendidikan keluarga, kesehatan mental tidak bisa dilepaskan, karena kesehatan mental para anggota keluarga merupakan tujuan dari pendidikan keluarga itu sendiri. Ketika pendidikan keluarga tersebut berjalan dengan baik, maka kesehatan mental dari keluarga tersebut akan berkembang dengan baik (Langgulung, 1992: 3). Begitu juga dengan sebaliknya, ketika pendidikan keluarga tidak berjalan dengan baik, maka kesehatan mental dari kelurga tersebut akan terganggu.

Sehubungan dengan uraian di atas, maka kajian ini bertujuan untuk membahas konsep pendidikan keluarga menurut Hasan Langgulung dan relevansinya dengan pengembangan kesehatan mental keluarga.

\section{METODE PENELITIAN}

Metode penelitian yang digunakan adalah penelitian tokoh dan lazim juga disebut dengan studi tokoh dengan pendekatan kualitatif deskriptif (Furchan, 2015: 9). Adapun sumber data yang digunakan dalam penelitian ini ada dua macam yaitu yang sifatnya primer dan skunder (Bogdan dan Biklen, 1992: 153). Data primer merupakan karya-karya Hasan Langgulung sendiri yang monumental yang memuat informasi tentang pendidikan Islam secara umum dan pendidikan keluarga secara khusus.

Sedangkan data skunder dalam penelitian ini adalah karya orang lain yang berisikan pandangan terhadap Hasan Langgulung. Data skunder ini dijadikan sebagai pendukung untuk menguatkan data primer. Analisis data yang digunakan dalam penelitian ini adalah analisis deskriptif, content analysis, dan analisis interpretatif (Zed, 2004: 1).

\section{HASIL PENELITIAN DAN PEMBAHASAN}

Hasan Langgulung merupakan seorang tokoh pendidikan Islam Indonesia yang telah lama berdomisili di negara tetangga Malaysia. Ia lahir di Rampang Sulawesi Selatan pada tangga 16 Oktober 1934 dari pasangan Tan Rasula dan Aminah Tansaruh. Hasan Langgulung menikah dengan Nuraimah Mohammad Yunus pada tanggal 22 September 1971 M. Dari hasil pernikahan ini mereka dikaruniai dua orang putra dan satu orang putri, yaitu Ahmad Taufiq, Nurul Huda, dan Siti Zakiyah. Hasan Langgulung tinggal di Malaysia tepatnya di Jalan B 28 Taman Bukit, Kajang (Langgulung, 2002: 299).

Hasan Langgulung meninggal dunia dalam usia 73 tahun pada tanggal 1 Agustus 2008 tepatnya pada pukul 19:45 waktu setempat, hari jum'at di rumah sakit Selayang Kuala Lumpur, karena menderita gagal ginjal. Jenazahnya dimakamkan selepas shalat zuhur di pemakaman taman Salih, Sentul Kuala Lumpur Malaysia (Langgulung, 2002: 299).

Hasan Langgulung menempuh pendidikan dasarnya di Sekolah Rakyat (SR) yang sekarang setingkat dengan Sekolah Dasar di Rappang Sulawesi Selatan. Setelah itu, ia melanjutkan jenjang pendidikannya di Sekolah Menengah Pertama dan Sekolah Menengah Islam di Ujung Pandang tahun 1949 sampai tahun 1952. Setelah itu ia melanjutkan kejenjang 
Sekolah Guru Islam Atas di Ujung Pandang pada tahun 1952 sampai 1955. Selain itu ia juga menempuh pendidkan B.I. Inggris di Ujung Pandang pada tahun 1957 sampai 1962 (Langgulung, 2002: 299).

Tidak puas sampai disitu, perjalanan pendidikannya dilanjutkan keluar negeri. Ia memutuskan hijrah ke Timur Tengah untuk menempuh pendidikan sarjana muda atau Bachelor of arts (BA) dengan spesialisasi Islamic and Arabic Studies yang ia peroleh dari Kairo University pada tahun 1957-1962. Setahun kemudian Langgulung sukses memperoleh gelar Diploma of Education tahun 1963 dan spesialis Diploma of Education tahun 1964 dari Ein Sham Universty, Mesir Kairo. Pada tahun yang sama Langgulung juga sempat memperoleh Diploma dalam bidang sastra Arab modern dari Institut of Higher Arab Studies, Arab League, Kairo. Setelah itu, Langgulung melanjutkan pendidikannya di Ein Syam University Kairo dan mendapatkan gelar M.A dalam bidang Psikologi dan Kesehatan Mental. Selanjutnya ia menempuh pendidikan S3 ke Barat. Sehingga ia mendapatkan gelar Doctor of Philosophy (Ph. D) dalam bidang psikologi dari University of Georgia, Amerika Serikat pada tahun 1971 (Amir, 2005: 55).

Sebagai putra pilihan dari Indonesia, Hasan Langgulung telah memberikan kontribusi yang sangat besar bagi perkembangan pendidikan di Malaysia. Salah satu jasa yang disumbangkan oleh Hasan Langgulung adalah Fakultas Pendidikan di Universitas Kebangsaan Malaysia (UKM) dan di Universitas Islam Internasional Malaysia. sebagai putra yang lahir di Indonesia, hingga akhir hidupnya ia tetap memilih menjadi warga negara Indonesia, meskipun telah menghabiskan waktu dan berkarir di Malaysia.

Selepas kuliah aktivitas Hasan Langgulung semakin sibuk. Langgulung sering kali menghadiri berbagai persidangan dan konfrensi baik sebagai pembicara maupun peserta yang diadakan di dalam maupun di luar negeri seperti di Amerika Serikat, Jepang, Australia, dan Timur Tengah, disamping Negara-negara yang ada di wilayah ASEAN. Pengalamannya sebagai pengajar dimulai sejak Langgulung masih kuliah di Mesir, yaitu sebagai kepala sekolah Indonesia di Kairo tahun 1957-1968. Saat di Amerika Serikat, Langgulung pernah dipercaya sebagai asisten pengajar dan dosen di University of Georgia tahun 1967-1970 dan sebagai asisten peneliti di Georgia Studies of Creative Behavior pada tahun 1970-1971. Setelah itu, ia diangkat sebagai asisten professor di Universitas Malaya, Malaysia pada tahun 1971-1972 (Amir, 2005: 56).

Langgulung juga pernah diundang sebagai Visiting professor di Universitas of Riyadh, Saudi Arabia dan di Cambridge University, Inggris pada tahun 1977-1978, dan sebagai konsultan psikologi di Stanford Research Institut, Menlo Park California, Amerika Serikat.

\section{Konseyp Pendidikan Keluarga Menurut Hasan Langgulung dan Relevansinya dengan Pengembangan Kesehatan Mental Keluarga}

Menurut Hasan Langgulung, keluarga sebagai lembaga pendidikan memiliki beberapa fungsi meliputi proses sosialisasi, nasehat, bimbingan, pengembangan bakat, minat dan potensi 
yang dimiliki oleh individu. Selain itu, keluarga harus menjauhkan anak-anak mereka dari berbagai persoalan yang menghalangi perkembangan potensinya. Fungsi pendidikan yang demikian merupakan tanggung jawab pokok dan bersifat kekal bagi keluarga itu sendiri. Oleh karena itu keluarga akan tetap menjadi lembaga pendidikan yang penting dan tidak akan pernah tergantikan oleh lembaga pendidikan lain meskipun konsep dan instusi pendidikan itu berubah (Langgulung, 1995: 356).

Peranan pendidikan yang dipegang oleh kedua orang tua dalam pendidikan keluarga merupakan peranan pokok dibandingkan dengan peranan-peranan yang lainnya. Lembaga-lembaga lainnya seperti lembaga politik, ekonomi, bahkan lembaga pendidikan formal sekalipun tidak dapat sepenuhnya mengemban peranan ini. Lembaga-lembaga pendidikan tersebut mungkin dapat menolong keluarga dalam melaksanakan pembangunan dalam bidang pendidikan namun tidak dapat menggantikan peranan keluarga secara keseluruhan (Langgulung, 1995: 360). Dengan kata lain, pendidikan di luar rumah hanyalah pendidikan yang menyempurnakan pendidikan yang dilaksanakan dalam rumah.

Keluarga sebagai instusi pendidikan yang penting, menurut Hasan Langgulung orang tua merupakan pemeran utama dalam mendidik anak. Setidaknya dalam mendidikan anak, orang tua memiliki peran dalam enam bidang pendidikan yaitu, pendidikan jasmani dan kesehatan, pendidikan intelektual, pendidikan psikologikal dan emosi, pendidikan agama, pendidikan ahklak, pendidikan sosial dan politik
(Langgulung, 1995: 363).

\section{Pendidikan Jasmani dan Kesehatan}

Pendidikan jasmani atau bisa disebut dengan pendidikan fisik karena ia berhubungan dengan tubuh atau fisik. Pendidikan jasmani adalah bentuk aktivitas yang dilakukan seseorang atau orang yang memberikan pelajaran dengan gerakan tubuh yang teratur dengan tujuan untuk meningkatkan berbagai kemampuan dan keterampilan tubuh. Hal ini dilakukan untuk menjaga kesehatan tubuh agar tetap semangat, kuat, aktif dan energik (Ath-Thur, 2007: 53).

Menurut Hasan Langgulung kedua orang tua memiliki peran penting dalam membantu pertumbuhan dan perkembangan jasmani anak, baik dari segi fungsi maupun bentuk dari fisik anak. Hal ini dapat dilaksanakan sebelum bayi lahir yaitu dengan menjaga kesehatan ibu selama mengandung (Langgulung, 1995: 364). Hasan Langgulung juga menyatakan bahwa berdasarkan al-Quran dan Hadis terkait dengan pendidikan jasmani dan kesehatan anak, orang tua memiliki peran dalam beberapa aspek yaitu:

Pertama, memenuhi kebutuhan gizi anak sejak masih dalam kadungan samapi ia besar, dalam hal ini dilakukan dengan memberikan ibu makanan yang sehat dan bergizi serta halal, setelah anak lahir diberikan ASI selama dua tahun sebagaimana firman Allah SWT. dalam al-Quran surat alBaqarah ayat 133 : 


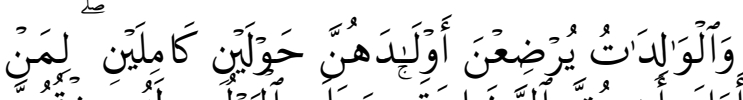

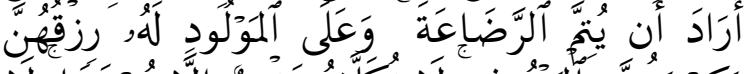

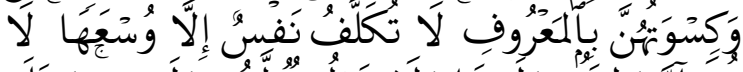

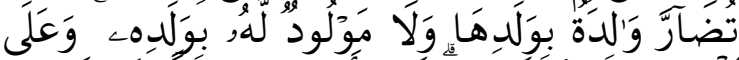

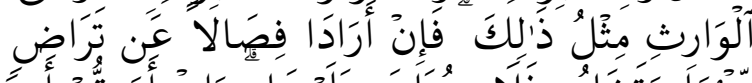

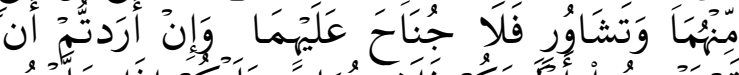

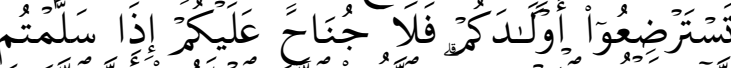

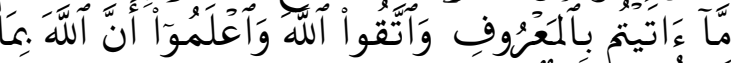

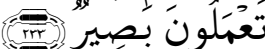

Artinya: Para ibu hendaklah menyusukan anak-anaknya selama dua tahun penuh, yaitu bagi yang ingin menyempurnakan penyusuan. dan kewajiban ayah memberi makan dan Pakaian kepada para ibu dengan cara ma'ruf. seseorang tidak dibebani melainkan menurut kadar kesanggupannya. Janganlah seorang ibu menderita kesengsaraan Karena anaknya dan seorang ayah Karena anaknya, dan warispun berkewajiban demikian. Apabila keduanya ingin menyapih (sebelum dua tahun) dengan kerelaan keduanya dan permusyawaratan, maka tidak ada dosa atas keduanya. Dan jika kamu ingin anakmu disusukan oleh orang lain, maka tidak ada dosa bagimu apabila kamu memberikan pembayaran menurut yang patut. Bertakwalah kamu kepada Allah dan Ketahuilah bahwa Allah Maha melihat apa yang kamu kerjakan. (QS. Al-Baqarah: 233).

Hasan Langgulung menegaskan bahwa memberikan peluang yang cukup bagi anak dalam menikmati susu ibu merupakan hal yang baik dan sangat dianjurkan. Karena menurut ASI mengandung makan jasmani, psikologikal, dan spritual yang akan membantu perkembangan jasmani anak dengan baik. Sedangkan ketiga kandungan ASI tersebut tidak terdapat pada susu botol walau bagaimana pun kandungan dan susunan bahan- bahannya (Langgulung, 1995: 364).

Kedua, menjaga kesehatan dan kebersihan jasmani dan pakaiannya. Orang tua harus bersifat protektif dalam mernjaga kesehatan anak, seperti melindunginya dari serangan binatang buas, melindunginya dari panas, dan menjauhkannya dari berbagai bahan minuman dan makanan yang berbahaya.

Ketiga, mengajarkan pola makan yang sehat yaitu dengan makan dan minum sesuai dengan kebutuhan sebagaimana firman Allah swt dalam al-Quran surat al-A'raf ayat 31:

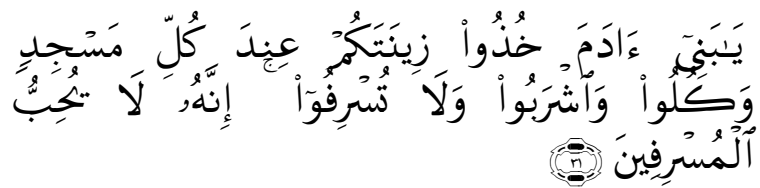

Artinya: Hai anak Adam, pakailah pakaianmu yang indah di setiap (memasuki) mesjid, makan dan minumlah, dan janganlah berlebih-lebihan. Sesungguhnya Allah tidak menyukai orang-orang yang berlebih-lebihan. (QS. Al'Araf: 31).

Keempat, mengajarkan anak akan keterampilan atau berolah raga dengan baik, seperti memanah dan berrenang, Umar Ibn Khattab mengatakan “ajarkan anak-anakmu berenang dan memanah serta melompat ke atas kuda." Menurut Hasan Langgulung dalam mendidik, membina, dan menanamkan konsep, ketermpilanketerampilan, kebiasaan-kebiasaan, dan sikap terhadap pertumbuhan dan 
perkembangan jasmani dan kesehatan anak sebagaimana di jelaskan di atas perlu memperhatikan tingkat perkembangan anak, sehingga ia akan mencapai kesehatan jasmani sesuai dengan usia, kematangan, dan pengamatan mereka (Langgulung, 1995: 365).

Pengetahuan orang tua tentang praktik-praktik kesehatan, seperti tentang gizi dan olah raga juga akan sangat membantu dalam pembinaan dan pendidikan jasmani dan kesehatan. Pendidikan dan pembinaan jasmani dan kesehatan pada masa anak-anak bukan hanya mempengaruhi kesehatan anak dimasa depan, akan tetapi juga berpengaruh terhadap perkembangan kepribadian dan penyesuaian dirinya ketika menginjak usia dewasa. Dengan demikian pendidikan jasmani dan kesehatan bagi anak bukan sekedar kebutuhan fisik saja, namun juga merupakan kebutuhan perkembangan kepribadiannya.

Dari pemaparan di atas dapat dikemukakan bahwa peranan orang tua dalam pendidikan jasmani dan kesehatan anak sudah dimulai sejak sebelum lahir, setelah bayi lahir sebaiknya orang tua memberikan ASI yang cukup kepada anak-anaknya, karena kandungan ASI memiliki manfaat yang besar terhedap perkembangan fisik dan spritual anak. Selain itu, orang tua juga harus memberikan tempat tinggal yang aman, memberikan pakaian dan makanan yang halal lagi baik, serta mengajrkan anak-anak berbagai hal yang bermanfaat bagi kebutuhan mereka. Sehingga dengan melaksakan proses pendidikan jasmani dan kesehatan tersebut anak dapat berkembang menjadi pribadi yang baik.

\section{Pendidikan Akal/Intelektual}

Pendidikan akal berarti adalah proses pembentukan nalar anak dengan segala disiplin keilmuan yang berbeda-beda dan bermanfaat dengan kebudayaan ilmiah modern yang diperlukannya, pencerahan pemikiran dan peradaban, sehingga nalarnya matang dan terbentuk secara ilmiah dan berperadaban serta mampu berpikir dengan benar dan independen (Ath-Thur, 2007: 174).

Menurut Hasan Langgulung walau pun pendidikan akal dikelola oleh instusi yang khsus seperti pendidikan formal, tetapi kedua orang tua tetap memiliki peranan yang sangat penting dan tidak dapat bebas dari tanggung jawab tersebut (Langgulung, 1995: 366). Pendidikan akal atau intlektual ini mencakup pembentukan pola pikir anak agar anak memiliki kematangan ilmu pengetahuan baik dalam hal agama, kebudayaan, peradaban dan lain-lain.

Diantara tugas dan peran kedua orang tua dalam hal ini adalah untuk menolong anak-anaknya membuka dan menumbuhkan bakat, minat, kemampuan akalnya dan sikap intlektual yang sehat dan melatih indra. Kedua orang tua juga harus menyiapkan suasana dan lingkungan yang sesuai dan mendorong mereka untuk belajar, mengulangi pelajaran, mengerjakan tugas, dan mengajari mereka cara belajar yang sesuai dengan tingkat kemampuan akal mereka. 


\section{Pendidikan Emosi/Psikologikal}

Selain dalam bidang pendidikan akal (intelektual), orang tua juga memiliki peran penting dalan pendidikan psikologikal dan emosi anak. Dimensi kejiwaan pada diri manusia merupakan suatu yang sangat urgen dan perlu untuk dibina dan dikembangkan agar dapat menghadapi berbagai masalah dengan cara yang tepat dan benar sejak anak masih dalam usia dini (Daradjat, 1994: 4).

Pendidikan psikologikal atau emosi merupakann pendidikan yang mencakup perasaan, emosi, inklinasi, kecenderungan dan sebagainya yang terkait dengan rohani manusia. Pendidikan emosi ini berawal dari ia menginjak tahap berfikir untuk bertindank mandiri, berterus terang, berani, senang melakukan kebaikan kepada orang lain, menekan amarah dengan menghiasi diri dengan semua keunggulan mental dan moral yang baik (Ath-Thur, 2007: 105).

Menurut Hasan Langgulung langkah pertama yang harus dilakukan oleh orang tua untuk mendidik dan memelihara anak-anaknya dari segi psikologi adalah mengetahui segala keperluan psikologi dan sosial anak, serta mengetahui kepentingan cara-cara memuaskannya untuk mencapai kesesuaian psikologi dari anak-anak. Selain itu, untuk mendidik dan memelihara psikologi anak, sebaiknya orang tua tidak melakukan pengabaian, ejekan, kekerasan dan membandingkan antara anaknya dengan anak saudara atau tetangganya (Langgulung, 1995: 369). Karena hal demikian akan berkibat pada penyimpangan kejiwaan pada anak.

\section{Pendidikan Agama/Spiritual}

Menurut Hasan Langgulung pendidikan agama merupakan bidang pendidikan bagi anak-anak yang harus mendapatkan perhatian penuh dari orang tua. Pendidikan ini dapat membangkitkan kesediaan agama dan spiritual yang bersifat naluri yang ada pada anak-anak melalui bimbingan agama yang sehat dan mengamalkan ajaran agama (Langgulung, 1995: 371). Fitrah islamiyah yang dibawa oleh anak sejak lahir hanya bisa berkembang dengan baik apabila kedua orang tuanya semaksimal mungkin berusaha untuk mengembangkan dan menjaga kefitrahannya. Tanpa usaha yang maksimal dari orang tua fitrah anak bisa menjadi rusak hingga berbalik menjadi kekufuran.

Oleh karena itu, untuk mencegah dan memelihara fitrah yang dibawa oleh anak tersebut, pendidikan agama menjadi hal mutlak yang harus diberikan kepada anak sejak dini. Dengan kata lain pendidikan agama bagi anak tidak bisa diabaikan begitu saja. Mengabaikannya sama artinya dengan mengabaikan fitrah islamiyah yang dibawa oleh anak sejak lahir. Anak yang dibesarkan tanpa pendidikan agama akan tumbuh sebagai pribadi yang jauh dari Allah, tidak mengenal sunnah dan buta terhadap agama (Al-Faruq, 2010: 137).

Menurut Hasan Langgulung untuk dapat menanamkan dan mengembangkan aspek pendidikan agama tersebut, kedua orang tua dapat melakukan beberapa cara berikut ini: Pertama, menguatkan keimanan kepada mereka agar senatiasa beriman kepada Allah swt dan berpengang teguh pada 
ajarannya; Kedua, membiasakan mereka melaksanakan syi'ar-syi'ar agama mulai dari yang kecil sampai yang besar sejak usia dini; Ketiga, menyiapkan suasana dan kondisi di rumah maupun di luar rumah yang agamis dan sesuai dengan ajaran Islam.

Membimbing mereka memahami agama dan memikirkan keesaan dan keagungan Allah (Langgulung, 1995: 172).

\section{Pendidikan Ahklak}

Menurut Hasan Langgulung, pendidikan akhlak dalam Islam merupakan bagian yang tidak bisa dipisahkan dari pendidikan agama, sebab tujuan dari pendidikan agama dalam Islam adalah mendidik jiwa dan akhlak anak. Kedua orang tua sebagai orang yang paling awal berinteraksi dengan anak, memengang peranan yang sangat penting dalam pendidikan akhlak untuk anak. Sebagai orang terdekat, mereka mendapat pengaruh dari segala prilaku kedua orang tua. Oleh karena itu, kedua orang tua harus mengambil posisi terkait dengan pendidikan ini, orang tua harus memberikan pengajaran tentang akhlak yang mulia menurut agama yaitu kejujuran, cinta kasih, pemberani, keikhlasan, pemurah dan sebagainya (Langgulung, 1995: 373).

Terkait dengan pendidikan akhlak ini, yang menjadi tujuan dari pendidikan dan pengajaran bukan hanya sekedar mentransfer berbagai ilmu pengetahuan kedalam otak anak. Tetapi lebih dari itu yaitu dengan mendidik akhlak mereka agar dapat berprilaku dengan baik.
Kedua orang tua perlu mengajarkan nilai-nilai serta faedahnya ketika anak berpengang teguh pada akhlak yang baik dalam kehidupannya sehari-hari, sehingga mereka termotivasi dengan membiasakan diri mereka berakhlak mulia sejak kecil (Langgulung, 1995: 374). Upaya orang tua pada priode anak-anak sangat penting, karena pada masa ini anak masih belum banyak berinteraksi dengan lingkungan lainnya, mudah menerima dan menyambut apa yang diajarkan. Sehingga pembiasaan dan pendidikan akhlak sejak kecil akan melekat hinga ia beranjak usia dewasa. Menurut Hasan Langgulung kewajiban orang tua dalam pendidikan akhlak berdasarkan al-Quran dan Hadis antara lain (Langgulung, 1995: 373). Pertama, memberikan keteladanan dalam berpegang teguh pada akhlak mulia. Orang tua yang tidak menerapkan akhlak mulia dalam kesehariannya akan lebih sulit untuk mendidik akhlak anak mereka; Kedua, menyediakan kesempatan dan ruang untuk anak memperaktikkan akhlak yang telah mereka pelajari dan orang tua; Ketiga, memberikan tanggung jawab yang sesuai kepada anak; Keempat, menunjukkan bahwa kedua orang tua selalu mengawasi prilaku mereka didalam dan di luar rumah dengan sadar dan bijaksana; Kelima, menjaga anak-anak dari pergaulan yang tidak baik.

Dari kelima tanggung jawab pendidikan akhlak ini, menurut Hasan Langgulung keteladanan orang tua menjadi hal utama yang harus dikedepankan. 


\section{Pendidikan Sosial}

Pendidikan sosial merupakan pendidikan yang mencakup pendidikan ekonomi dan politik. Menurut Hasan Langgulung tujuan pendidikan ini adalah agar anak dapat tampil dimasyarakat sebagai generasi yang mampu berinteraksi dengan dunia sosial dengan baik, beradab, berakal matang, dan berprilaku yang bijaksana (Langgulung, 1995: 376). Sehingga dengan kemapuan itu anak akan mampu memberikan kontribusi yang positif dalam masyarakat luas (Suwaid, 2003: 202).

Terkait dengan pendidikan sosial ini, Hasan Langgulung menyatakan bahwa manusia itu bukan hanya makhluk bilogis yang memerlukan kebutuhan secara fisik. Namun manusia itu juga makhluk sosial, oleh sebab itu selain dari keperluan biologis ia juga memiliki keperluan sosial dan psikologis. Dengan kata lain, manusia hidup bukan hanya perlu makan, minum, tidur dan lain-lain, tetapi juga perlu ilmu pengetahuan, berkeluarga, berorganisasi, perlu kasih sayang, perlu dihargai dan diperhatikan (Langgulung, 1985: 177). Ini semua merupakan kebutuhan mutlak manusia secara sosial dan psikologis. Oleh karena itu, orang tua semestinya memberikan pendidikan sosial kepada anak untuk memenuhi kebutuhan tersebut.

Keluarga belum melengkapi tugasnya dengan sempurna dalam mendidik anak-anak jika belum memberikan pendidikan sosial bagi mereka. Pendidikan sosial adalah mendidik anak sejak kecil agar terbiasa menjalankan prilaku sosial yang utama, dasar-dasar kejiwaan yang mulia yang bersumber dari akidah islamiyah yang kekal dan kesadaran iman yang mendalam, agar ditengah-tengah masyarakat nanti ia mampu bergaul dan berprilaku sosial yang baik, memiliki keseimbangan akal yang matang dan tindakan yang bijaksana (Ulwan, 2007: 435).

\section{Relevansi Konsep Pendidikan Keluarga Menurut Hasan Langgulung dengan Pengembangan Kesehatan Mental Keluarga}

Hasan Langgulung sebagai seorang ilmuan, tidak hanya membahas bidang pendidikan Islam saja, tetapi juga banyak membicarakan tentang bidang yang lain seperti psikologi dan kesehatan mental. Hal ini terlihat dari berbagai karya ilmiah yang telah ditulisnya, disamping menulis beberapa buku tentang pendidikan Islam, Hasan Langgulung juga menulis beberapa karya lainnya tentang kesehatan mental.

Berdasarkan hasil analisis penulis terhadap beberapa karyanya, pemikiran Hasan Langgulung tentang pendidikan keluarga Islam memiliki relevansi dengan pengembangan kesehatan mental keluarga. Dengan kata lain, penerapan konsep pendidikan keluarga yang diusung oleh Hasan Langgulung memiliki kontribusi yang besar terhadap pengembangan kesehatan mental keluarga. Oleh karena itu, dalam pembahasan ini akan dilihat relevansi konsep pendidikan keluarga menurut Hasan Langgulung dengan pengembangan kesehatan mental keluarga.

Mengawali pembahasan ini, terlebih dahulu diulas tentang kesehatan 
mental dalam persfektif Hasan Langgulung. Menurut pengamatan Hasan Langgulung, dalam al-Quran istilah kesehatan mental digunakan dengan berbagai istilah yaitu najat (keselamatan), faws (keberuntungan), Falah (kemakmuran), dan sa'dah (kebahagiaan). Menurut Hasan Langgulung kesehatan mental adalah keselamatan dan kebahagiaan dalam bentuk pertama yaitu yang berlaku di dunia. Dalam Islam menurut Hasan Langgulung kebahagian di dunia dan di akhirat tidak dapat dipisahkan, karena kehidupan dunia menjadi jalan kebahagian di akhirat (Langgulung, 1986: 444). Disisi lain Hasan Langgulung menjelaskan bahwa dalam Islam, kesehatan mental itu dapat disimpulkan sebagai akhlak yang mulia. Dengan demikian kesehatan mental juga dapat didefinisikan sebagai keadaan jiwa yang menyebabkan seseorang menjadi ikhlas dan merasa tentram ketika ia melaksanakan akhlak yang mulia dan menjauhi akhlak yang buruk (Langgulung, 2002: 165).

Kesehatan mental yang dipahami sebagai akhlak mulia menghendaki seseorang dapat menjalin hubungan yang baik dengan Allah, manusia, dan dengan dirinya agar ia dapat berkembang secara keseluruhan dan berpadu dalam empat dimensi yaitu jasmani, mental sosial, dan spiritual (Langgulung, 2002: 66). Hubungan yang baik dengan Allah berarti mengenal dan mencintai Allah dengan hati yang ikhlas, melaksanakan segala perintah dan menjauhkan diri dari berbagai bentuk larangan-Nya. Selanjutnya Allah akan mencintainya dan memudahkan segala urusan hambanya, serta membersihkan lahir dan batinnya.

\section{PENUTUP}

Pandangan Hasan Langgulung tentang pendidikan keluarga, ada enam aspek yang menjadi tanggung jawab orang tua dalam mendidik anaknya, yaitu; pendidikan jasmani/kesehatan, pendidikan akal/ intelektual, pendidikan, Emosi/ psikologikal, pendidikan agama/spiritual, dan pendidikan sosial. Masing-masing dari aspek pendidikan ini merupakan bagian integral yang tidak bisa dipisahkan antara satu dengan yang lainnya.

Pendidikan keluarga yang mencakup enam aspek sebagaimana disebutkan di atas, sangat berpengaruh kepada kesehatan mental seorang anak. Apabila seluruh aspek pendidikan telah terlaksana dengan baik maka kesehatan mental anak akan menjadi baik dengan sendirinya. Menurut Hasan Langgung, kesehatan mental memiliki kesamaan dengan akhlak mulia, seseorang dikatakan sehat mentalnya apabilan ia memiliki akhlak yang baik dalam kehidupannya.

\section{REFERENSI}

Al-Faruq, Asadullah, Mendidik Balita Mengenal Agama, Solo: Kiswah Media, 2010

Amir, Dinasril, Pendidikan dan Kesehatan Mental Pemikiran Hasan Hasan Langgulung, Padang: The Minangkabau Foundation, 2005

Ath-Thur, Hannan Athiyah, Mendidik Anak Perempuan di Masa KanakKanak, Jakarta: Amzah, 2007 
Bogdan, Robert C dan Biklen Sari Knopp, Qualitative Research For Education: An Introductiont to Theory and Methods, London: Allin and Bacon 1992

Daradjat, Zakiah, Ilmu Pendidikan Islam, Jakarta: Bumi Aksara, 1996

Daradjat, Zakiah, Pendidikan Islam dalam Keluarga dan Sekolah, Jakarta: Ruhama, 1994

Djamarah, Syaiful Bahri, Pola Asuh Orang Tua dan Komunikasi dalam Keluarga, Jakarta: Rineka Cipta, 2014

Furchan, Arief dan Maimun, Agus, Studi Tokoh: Metode Penelitian Mengenai Tokoh, Yogyakarta: Pustaka Pelajar, 2005

Jaya, Yahya, Peranan Taubat dan Maaf dalam Kesehatan Mental, Cet. 3, Jakarta: Ruhama, 1995

Karwadi, "Tujuan Pendidikan Islam dalam Pemikiran Hasan Langgulung", dalam At-Tarbiyah: Jurnal PAI, Vol. 4, No. 2 Tahun 2009

Kementerian Agama Republik Indonesia, al-Quran dan Terjemahnya, Jarkarta: Pustaka Jaya Ilmu, 2012
Langgulung, Hasan, Manusia dan Pendidikan: Analisis Psikologis, Filsafat dan Pendidikan, Jakarta: Pustaka al-Husna Baru, 2004

Langgulung, Hasan, Pendidikan dan Peradaban Islam: Suatu Analisa Sosio-Psikologi, Jakarta: Pustaka alHusna, 1985

Langgulung, Hasan, Peralihan Pradigma dalam Pendidikan Islam dan Sains Sosial, Jakarta: Gaya Media Pratama, 2002

Langgulung, Hasan, Teori-Teori Kesehatan Mental, Cet. II, Jakarta: Pustaka alHusna, 1992

Musmalim, "Eksistensi Pendidikan Luar Sekolah", dalam Majalah Pendidikan Sang Guru. Edisi 014 Tahun 2011

Suwaid, Muhammad Nur Abdul Hafiz, Mendidik Anak Bersama Nabi, ter. Solo: Pustaka Arafah, 2003

Zed, Mestika, Metode Penelitian Kepustakaan, Jakarta: Yayasan Obor Indonesia, 2004 
24 || Turast: Jurnal Penelitian dan Pengabdian Vol. 6, No. 1, Januari-Juli 2018 
